\author{
AnNA KAPAEA ${ }^{1}$
}

\title{
Wsparcie produktów regionalnych i tradycyjnych w ustawodawstwie krajowym na przykładzie prawa włoskiego
}

\section{Wprowadzenie}

Rozważania dotyczą szeroko rozumianych produktów regionalnych i tradycyjnych, w tym produktów objętych systemem jakości uregulowanych w rozporządzeniu (UE) nr 1151/2012, ${ }^{2}$ tj. chronionej nazwy pochodzenia (ChNP), chronionego oznaczenia geograficznego (ChOG) oraz gwarantowanej tradycyjnej specjalności (GTS). Wsparcie i promocja wskazanych systemów, zarówno w ramach I i II filaru wspólnej polityki rolnej (WPR), wyznaczone jest regulacjami unijnymi. Na podstawie rozporządzenia UE 1305/2013 ${ }^{3}$ państwa członkowskie wdrażają w krajowych Programach Rozwoju Obszarów Wiejskich (PROW) działania skierowane na uczestnictwo w systemach jakości, akcje informacyjne i promocyjne. W ramach I filaru rozporządzenie UE 1307/2013 ${ }^{4}$ umożliwiło państwom członkowskim podjęcie decyzji o przeznaczeniu części środków (15\%) z puli płatności bezpośrednich na różne działania z II filaru, w tym dotyczące jakości produkcji. Poza realizacją określonych przez prawo UE możliwości, ustawodawca krajowy może przewidzieć również regulacje sprzyjające promocji i sprzedaży produktów lokalnych lub objętych systemem jakości. Rozporządzenie (UE) 1151/2012 jest natomiast wyczerpujące w zakresie ochrony systemów jakości, dlatego nie mogą mieć w tej kwestii zastosowania krajowe przepisy własności intelektualnej. ${ }^{5}$

$1 \quad$ Uniwersytet Przyrodniczy we Wrocławiu.

2 Rozporządzenie Parlamentu Europejskiego i Rady (UE) nr 1151/2012 z dnia 21 listopada 2012 r. w sprawie systemów jakości produktów rolnych i środków spożywczych (Dz.Urz. UE L 343 z dnia 14 grudnia 2012 r., s. 1). Rozporządzenie Parlamentu Europejskiego i Rady (UE) nr 1305/2013 z dnia 17 grudnia 2013 r. w sprawie wsparcia rozwoju obszarów wiejskich przez Europejski Fundusz Rolny na rzecz Rozwoju Obszarów Wiejskich (EFRROW) i uchylające rozporządzenie Rady (WE) nr 1698/2005, (Dz.Urz. UE L 347 z dnia 20 grudnia 2013, S. 487).

4 Rozporządzenie Parlamentu Europejskiego i Rady (UE) nr 1307/2013 z dnia 17 grudnia 2013 r. ustanawiające przepisy dotyczące płatności bezpośrednich dla rolników na podstawie systemów wsparcia w ramach wspólnej polityki rolnej oraz uchylające rozporządzenie Rady (WE) nr 637/2008 i rozporządzenie Rady (WE) nr 73/2009, (Dz.Urz. UE L 347 z dnia 20 grudnia 2013 r., s. 608).

5 Zob. wyrok Trybunału (wielka izba) z dnia 8 września 2009 r. w sprawie Budĕjovický Budvar, národní podnik przeciwko Rudolf Ammersin $\mathrm{GmbH}$ Budĕjovický, C-478/07, http://curia.europa.eu/juris/liste.jsf?langu- 
Włochy są obecnie liderem w Europie pod względem liczby zarejestrowanych nazw pochodzenia i oznaczeń geograficznych. ${ }^{6}$ Niewątpliwie na ten fakt rzutują wyjątkowe predyspozycje tego kraju do produkcji żywności wysokiej jakości, dzięki wielowiekowym tradycjom, umiejętnościom i bogatemu dziedzictwu kulinarnemu. Być może jednak poza tymi czynnikami, do sukcesu systemów jakości we Włoszech przyczyniają się również wewnętrzne przepisy, które sprzyjają ich promocji i sprzedaży. Dlatego wydaje się interesujące zbadanie włoskich rozwiązań w tej kwestii, które mogą w przyszłości posłużyć jako punkt odniesienia dla polskiego ustawodawcy oraz dalszych naukowych badań prawnoporównawczych. Dotychczas w literaturze prawnorolnej temat ten nie był bliżej opracowany.

Celem rozważań jest wskazanie, w jaki sposób ustawodawca włoski wspiera promocję i sprzedaż produktów regionalnych i tradycyjnych, w tym objętych unijnym systemem jakości. Dla realizacji wskazanego celu analizie zostaną poddane przepisy dotyczące wdrożenia w ramach PROW działania określonego art. 16 w rozporządzenia UE nr 1305/2013 oraz regulacje krajowe i regionalne dotyczące różnych form promocji i sprzedaży produktów.

\section{Wdrożenie art. 16 rozporządzenia (UE) 1305/2013 we włoskich Programach Rozwoju Obszarów Wiejskich}

We Włoszech na podstawie art. 117 Konstytucji Republiki Włoch ${ }^{7}$ przyjmuje się, że rolnictwo należy do kompetencji ustawodawczej regionów, dlatego Programy Rozwoju Obszarów Wiejskich przygotowywane są przez każdy z 20 regionów. Zgodnie z orzeczeniem Sądu Konstytucyjnego Włoch państwo ma prawo wydawać przepisy ramowe, stanowiące tzw. rdzeń i obowiązujące wszystkie regiony, które następnie wdrażają i rozwijają je, dostosowując do lokalnych potrzeb i uwarunkowań. ${ }^{8} \mathrm{~W}$ niniejszych rozważaniach będą przybliżone, jako przykład, rozwiązania PROW Regionu Piemonte. ${ }^{9}$

Beneficjentem poddziałania „Wsparcie na przystępowanie do systemów jakości” według PROW Regionu Piemonte mogą być, zgodnie z art. 16 ust. 1 rozporządzenia 1305/2013, rolnicy aktywni zawodowo, a także ich grupy, którzy po raz

Według stanu na 20 września 2016 r. w rejestrze Komisji Europejskiej jest 285 włoskich produktów zarejestrowanych w ramach systemów jakości, w tym 165 ChNP, 118 ChOG, 2 GTS, zob. na stronie Komisji Europejskiej: http://ec.europa.eu/agriculture/quality/door/list.html.

7 Costituzione della Repubblica Italiana (GU nr 298 z 27.12.1947).

8 Sentenza Corte Costituzionale nr 116/2006 (GU nr 12 z 22.03.2006), www.cortecostituzionale.it.

9 PROW dla Regionu Piemonte na lata 2014-2020 został zatwierdzony przez KE decyzją C(205)7456 z 28 października 2015 r. przyjęty przez Region Piemonte uchwałą Rady Regionalnej D.G.R. nr 29-2396 z listopada 2015 r. (D.G.R. 9 Novembre 2015, n. 29-2396 Regolamento (CE) n. 1305/2013 sul sostegno allo sviluppo rurale da parte del FEASR: Programma di Sviluppo Rurale 2014-2020 della Regione Piemonte approvato dalla Commissione europea con decisione C(2015)7456 del 28 ottobre 2015. Recepimento del testo definitivo del Programma e disposizioni organizzative. (BU nr 45, Supplemento Ordinario n. 2). 
pierwszy przystępują do uczestnictwa przynajmniej w jednym systemie jakości. Pojęcie grupy rolników wyjaśnione jest w Programie. Oznacza ono „w szczególności, że zrzeszają, przede wszystkim rolników aktywnych zawodowo, uczestniczących po raz pierwszy w systemach jakości produktów rolnych i środków spożywczych, na przykład, organizacje producentów rolnych i ich związki, uznane na podstawie przepisów unijnych, krajowych i regionalnych; grupy zdefiniowane w art. 3 ust. 2 rozporządzenia UE 1151/2012, łącznie z konsorcjami ochrony ChNP, ChOG i GTS, uznanymi na podstawie przepisów krajowych, w szczególności art. 53 ustawy 128/1998 ${ }^{10}$ zastapionego przez art. 14 ustawy 526/1999; ${ }^{11}$ grupy producentów rolnych wskazanych $\mathrm{w}$ art. 95 rozporządzenia UE $\mathrm{nr}$ 1308/2013, ${ }^{12} \mathrm{w}$ tym konsorcja ochrony uznawane na mocy prawa krajowego, w szczególności art. 17 dekretu z mocą ustawy 61/2010; zrzeszenia rolników ustanowione na mocy ustawodawstwa krajowego; spółdzielnie rolnicze i ich zrzeszenia; zgrupowania producentów rolnych utworzonych w sieciach korporacyjnych, lub grupy lub zespoły utworzone jako Tymczasowe Stowarzyszenie Celowe lub Tymczasowe Zrzeszenie Wspólnego Celu, powołane w trybie przepisów o zamówieniach publicznych". ${ }^{13}$

Pojęcie aktywni rolnicy rozumiane jest zgodnie $\mathrm{z}$ art. 9 rozporządzenia (UE) nr 1307/2013 i rozporządzeniem ministerialnym nr 6513 z dnia 18 listopada 2014. ${ }^{14}$ W celu otrzymania wsparcia wnioskodawcy muszą, po złożeniu wniosku, przystąpić po raz pierwszy do co najmniej jednego systemu jakości. Kryteria wyboru preferują podmioty kolektywne. Najwięcej punktów jest przyznawanych, jeżeli wniosek składa grupa „w ramach podejścia zbiorowego” lub „,w ramach projektu zintegrowanego łańcucha dostaw". ${ }^{15}$

Szeroko określony zakres podmiotowy wskazuje, że intencją ustawodawcy regionalnego było nie tylko wsparcie pojedynczych rolników, ale także tych działających w różnego rodzaju grupach. Przy czym grupy, jak stanowi uchwała, nie muszą obejmować „wyłącznie” rolników aktywnych zawodowo. Mogą zatem w ich skład wchodzić producenci lub przetwórcy, uczestniczący w łańcuchu produkcyjnym danego produktu, niemający statusu rolnika aktywnego zawodowo.

Legge 24 aprile 1998, n. 128 Disposizioni per l'adempimento di obblighi derivanti dalla appartenenza dell'Italia alle Comunita' europee. Legge comunitaria 1995-1997. (GU Serie Generale nr 104 z 07.05.1998 - Suppl. Ordinario n. 88).

11 Legge 21 dicembre 1999 n.526 Disposizioni per l'adempimento di obblighi derivanti dall'appartenenza dell'Italia alle Comunita' europee - Legge comunitaria 1999. (GU nr 13 z 18.01.2000).

12 Rozporządzenie Parlamentu Europejskiego i Rady (UE) nr 1308/2013 z dnia 17 grudnia 2013 r. ustanawiające wspólną organizację rynków produktów rolnych oraz uchylające rozporządzenia Rady (EWG) nr 922/72, (EWG) nr 234/79, (WE) nr 1037/2001 i (WE) nr 1234/2007 (Dz.Urz. UE L 347/671 z dnia 20 grudnia 2013 r.).

13 Zob. Bando $n^{\circ}$ 1_/2016_Regione Piemonte_Misura 03 Regimi di qualità dei prodotti agricoli e alimentari (art. 16) Sottomisura 3.1. Sostegno alla nuova adesione a regimi di qualità Operazione 3.1.1. Partecipazione a regimi di qualità, wydanego na podstawie: Programma di sviluppo rurale 2014-2020 del Piemonte (PSR) - DGR n. 212864 del 01.02.2016. Approvazione bando di apertura per presentazione delle domande sulla Operazioni 3.1.1 "Partecipazione ai regimi di qualità" (D.G.R. nr 21 - 2864 BU della Regione Piemonte).

14 Decreto Ministro Delle Politiche Agricole Alimentari e Forestali, n. 653 del 12 maggio 2015, Ulteriori disposizioni relative alla gestione della PAC 2014-2020. (15A04736) (GU Serie Generale nr 144 z 24.06.2015). Zob. Bando n¹_/2016_Regione Piemonte_Misura 03, op. cit. 
Zakres podmiotowy, akcentujący różne formy łączenia się rolników i producentów, jest uzasadniony w opisie celów działania, w którym podkreśla się, że „uczestnictwo w systemach jakości skłania producentów do integrowania się ze sobą i stosowania wspólnych zasad w celu zapewnienia odpowiedniej jakości ich produktów". Łączenie się umożliwia „wprowadzanie procedur produkcyjnych o wyższych standardach jakości oraz tworzenie bardziej konkurencyjnych i efektywnych struktur organizacyjnych". ${ }^{16}$

Warunki PROW regionu Piemonte nie są odosobnione. Podobnie szeroki zakres podmiotowy beneficjentów określają programy innych regionów. Na przykład zgodnie z PROW Regionu Marche do omawianego działania może przystąpić albo pojedynczy rolnik, będący rolnikiem aktywnym zawodowo, albo grupa rolników, która powinna zrzeszać „także” (a więc niewyłącznie) rolników aktywnych zawodowo. Ponadto grupa może być podmiotem promującym łańcuch jakości w ramach PROW 2007-2013 lub PROW 2014-2020. Podmiot, będący promotorem może obejmować także podmioty inne niż rolnicy, przetwarzające produkty niezawarte $\mathrm{w}$ Załączniku I do Traktatu UE, dla których pomoc zostanie wypłacona w systemie de minimis $\mathrm{w}$ rozumieniu rozporządzenia UE $\mathrm{nr}$ 1407/2013 ${ }^{17} \mathrm{i}$ zgodnie z przepisami Uchwały Rady Regionalnej nr 42 z dnia 18 stycznia 2016 r. ${ }^{18}$ Również w tym Programie podkreślony jest cel ,wzmocnienia roli podmiotów zrzeszeniowych w łączeniu dostaw w ramach łańcucha jakości”. ${ }^{19}$

Wytwarzanie produktu w ramach grupy znajduje swoje uzasadnienie z punktu widzenia optymalizacji kosztów i organizacji produkcji i sprzedaży. Liczba produktów otrzymywanych przez pojedynczych rolników może być tak znikoma, że przetwarzanie lub opakowywanie ich może być niemożliwe lub niepraktyczne. Te dodatkowe czynności są czasami warunkiem koniecznym, aby poinformować i przekonać klienta, że produkt jest wyjątkowy i warto za niego zapłacić. Ponadto bardzo często w małych gospodarstwach brakuje umiejętności biznesowych i możliwości finansowych niezbędnych do uwidocznienia wartości dodanej produktu w długich i złożonych kanałach sprzedaży. ${ }^{20}$ Ograniczenie rozmiarowe producentów, w sensie strukturalnym, organizacyjnym, kapitałowym i wielkości produkcji niewątpliwie

Ibidem.

Rozporządzenie Komisji (UE) nr 1407/2013 z dnia 18 grudnia 2013 r. w sprawie stosowania art. 107 i 108 Traktatu o funkcjonowaniu Unii Europejskiej do pomocy de minimis. Tekst mający znaczenie dla EOG (Dz.Urz. UE L 352 z 24 grudnia 2013 r.).

Decreto del Dirigente del Servizio Ambiente e Agricoltura n. 42 del 18.1.2016 Oggetto: Reg. (CE) n. 1305/2013 Programma di Sviluppo Rurale della Regione Marche 2014-2020 - Bando - Sottomisura 6.4. sostegno a investimenti nella creazione e nello sviluppo di attività extra-agricole Operazione A) Azione 1 - Agriturismo: Sviluppo di attività non agricole nel settore dell'agriturismo.

Programma di Sviluppo Rurale 2014-2020 Regione Marche. Bando Mis.3 - Regimi di Qualità dei Prodotti Agricoli e Alimentari, Allegato A al Decreto del Dirigente del Servizio Ambiente e Agricoltura n. 151 del 22 marzo 2016, Oggetto: Reg. (UE) n. 1305/2013 - Programma di Sviluppo Rurale della Regione Marche 2014/2020 Bando - Sottomisura 3.1 A - "Supporto a titolo di incentivo per i costi di partecipazione ai sistemi di qualità".

A. Carbone, La valorizzazione della qualità agroalimentare: diverse strategie a confronto, Agriregionieuropa 2016, nr 2, s. 4, www.agriregionieuropa.univpm.it. 
Wsparcie produktów regionalnych i tradycyjnych w ustawodawstwie krajowym...

jest barierą korzystania z systemów jakości. ${ }^{21}$ Problem ten jest zwłaszcza aktualny w przypadku nowych nazw i oznaczeń, które muszą utorować sobie drogę na rynku produktów jakościowych.

Warto w tym kontekście spojrzeć na warunki dostępu do działania w polskim PROW. W rozumieniu rozporządzenia z dnia 6 sierpnia 2015 r. w sprawie szczegółowych warunków i trybu przyznawania, wypłaty oraz zwrotu pomocy finansowej w ramach poddziałania „Wsparcie na przystępowanie do systemów jakości”, objętego Programem Rozwoju Obszarów Wiejskich na lata 2014-2020, pomoc jest przyznawana rolnikowi aktywnemu zawodowo. ${ }^{22}$ Przepis pomija grupy rolników, chociaż art. 16 ust. 1 rozporządzenia 1305/2013, będący podstawą prawną omawianego działania, stanowi, że wsparcie obejmuje rolników i grupy rolników. Polski prawodawca zdecydował przeznaczać wsparcie wyłącznie bezpośrednio dla poszczególnych rolników, zwłaszcza posiadających małe gospodarstwa rolne, ustanawiając preferencję dla gospodarstw o powierzchni między 5 a 10 ha. Zapewne jego intencją było, aby w ten sposób środki trafiły do konkretnego rolnika, który może je wykorzystywać na pokrycie własnych kosztów „kontroli, w tym badań i analiz wykonanych w związku z kontrolą" lub składek ,na rzecz grupy producentów, do której przynależy, działającej w jednej z form organizacyjnych wymienionych w załączniku do rozporządzenia”, lub ,zakupu specjalistycznych publikacji, związanych z prowadzeniem produkcji w zakresie systemu jakości, którego dotyczy wniosek o przyznanie pomocy" ( $\$ 10$ ust. 3 rozporządzenia z dnia 6 sierpnia 2015 r.).

Refundacja poniesionych kosztów jest stosunkowo niska, wynosząc maksymalnie 3200 zł, co nie dziwi w kontekście ich ograniczonego katalogu. W omawianym PROW włoskiego Regionu Piemonte zakres refundowanych kosztów jest podobnie określony. Wskazane koszty nie dotyczą zatem podniesienia standardów produkcji lub ponoszenia przez grupę wspólnego wysiłku organizacyjnego w procesie produkcji. Jednak w przypadku włoskiego PROW, nawet jeżeli wniosek składa grupa producentów, pomoc (w wysokości nieprzekraczającej 3000 euro) odnosi się do każdego z poszczególnych rolników wchodzących w skład grupy. Ponadto może być wypłacana przez 5 lat, a według polskiego PROW obejmuje okresy trzech kolejnych dwunastu miesięcy.

$\mathrm{Z}$ analizy wynika, że według warunków włoskiego PROW, środki przeznaczane są na poszczególnych rolników (tak jak w przypadku polskiego PROW), nawet jeżeli wnioskodawcą jest grupa. Włoski PROW umożliwia staranie się o pomoc nie tylko indywidualnym rolnikom, ale też ich grupom, podkreślając znaczenie zrzesza-

21 Ibidem.

22 Rozporządzenie Ministra Rolnictwa i Rozwoju Wsi z dnia 6 sierpnia 2015 r. w sprawie szczegółowych warunków i trybu przyznawania, wypłaty oraz zwrotu pomocy finansowej w ramach poddziałania „Wsparcie na przystępowanie do systemów jakości” objętego Programem Rozwoju Obszarów Wiejskich na lata 2014-2020 (Dz.U. z 2015 r. poz. 1195). 
nia się i znajdowania różnych form wspólnej realizacji etapów produkcji lub sprzedaży. Przy czym grupa, jak wskazują warunki analizowanych włoskich PROW nie musi się składać w sposób wyłączny z rolników aktywnych zawodowo. Mogą więc do nich należeć także producenci lub przetwórcy, niespełniający kryterium rolnika zawodowego, ale odgrywający istotną rolę w łańcuchu produkcyjnym. Produkt objęty systemem jakości nie musi przecież być wyłącznie produktem rolnym, ale również środkiem spożywczym, otrzymanym z przetworzonych produktów.

Drugim działaniem w ramach systemów jakości, na które państwa członkowskie mogą przeznaczyć środki unijne na podstawie art. 16 ust. 2 rozporządzenia UE $1305 / 2013$ są działania informacyjne i promocyjne prowadzone przez grupy producentów na rynku wewnętrznym, dotyczące produktów objętych systemami jakości, otrzymujących wsparcie na działania na przystępowanie do systemów jakości. W wypadku tego działania rozporządzenie UE nie posługuje się już pojęciem rolników lub grupy rolników, ale ,grupy producentów”.

Ze względu na ograniczone ramy artykułu powyższe działanie nie będzie bliżej omawiane. Warto jednak zaznaczyć, że zakres podmiotowy określony dla tego poddziałania w PROW Regionu Piemonte jest jeszcze szerszy niż w poprzednio omówionym poddziałaniu, obejmując dodatkowo organizacje producentów i ich stowarzyszenia, uznane przez przepisy UE, krajowe i regionalne oraz organizacje międzybranżowe uznane na podstawie przepisów unijnych, krajowych, regionalnych. ${ }^{23}$ Ponadto przewidziany został wymóg, aby podmiot zgłaszający wniosek był reprezentatywny dla produkcji i systemów jakości, których dotyczy wniosek, a w przeciwnym razie powinien zobowiązać się do stworzenia tymczasowego stowarzyszenia przedsiębiorstw lub tymczasowego stowarzyszenia celowego z innymi podmiotami, tak aby ustanowione stowarzyszenie było reprezentatywne dla systemów jakości i produktów, których wniosek dotyczy.

Warto zwrócić uwagę na różne formy łączenia się i współpracy rolników we Włoszech, jak sieci przedsiębiorstw oraz tymczasowe stowarzyszenia przedsiębiorstw lub tymczasowe stowarzyszenia celowe. Sieć przedsiębiorstw to instytucja prawna, która została wprowadzona do włoskiego porządku prawnego w 2009 r. (legge 33/2009). ${ }^{24}$ Jest to umowa, która łączy przedsiębiorców wokół wspólnego celu, tj. ,zwiększenia, indywidualnie i zbiorowo, własnego potencjału innowacyjnego i konkurencyjności na rynku” (legge 33/2009). Pozwala przedsiębiorcom współ-

Bando $n^{\circ}$ 1_/2016_A Regione Piemonte Azioni di informazione e promozione da svolgere nell'ambito di fiere e manifestazioni a carattere internazionale e strategiche.

24 W drodze art. 3 ust. 4 ter D. L. 10/02/2009, n. 5, convertito in L. del 09/04/2009, n. 33, zmienionego wielokrotnie przez art. 1, comma 1, della L. del 23 luglio 2009, n. 99, contenente "disposizioni per lo sviluppo e l'internazionalizzazione delle imprese, nonché in materia di energia", e, successivamente, dall'art. 42, comma 2 bis, della L. del 30 luglio 2010, n. 122, recante "misure urgenti in materia di stabilizzazione finanziaria e di competitività economica". L'ultimo aggiornamento dell'istituto è avvenuto con il c.d. Decreto Sviluppo del 2012 (D.L. 83/2012 convertito con modificazioni dalla L. 134/2012). 
pracować w ramach sieci, realizując wspólny projekt, bez utraty swojej autonomii i niezależności. Celem umowy sieci, inaczej niż w przypadku konsorcjów, nie jest wspólne wykonywanie działalności gospodarczej i w przeciwieństwie do innych form zrzeszania się, sieć jest prostą formą umowy. Nie wymaga ustanowienia organów, ani kapitału zakładowego (choć nie wyklucza takiej możliwości), ale pozwala przedsiębiorcom być bardziej konkurencyjnymi. Współpracują oni ze sobą w różnych formach (takich jak: ,,wymiana informacji lub usług o charakterze przemysłowym, handlowym, technicznym lub technologicznym, albo wspólne wykonywanie jednej lub więcej czynności objętych zakresem swojej działalności" legge 33/2009), aby zwiększyć ekonomię skali lub wdrożyć projekty wykorzystujące nowe know-how.

Tymczasowe stowarzyszenie przedsiębiorstw jest formą łączenia się, niebędącą, podobnie jak sieć, ani spółką ani konsorcjum. Tworzone jest wyłącznie przez przedsiębiorstwa, co najmniej dwa (również rolne). Nie musi posiadać swojego statutu, organów, ani kapitału zakładowego lub funduszu konsorcyjnego. Jest to zatem również prosta forma prawna, pozbawiona „biurokracji”. Jest stosowana najczęściej w celu uczestnictwa w przetargach publicznych. Podobną formą prawną jest tymczasowe stowarzyszenie celowe. Różni się jedynie od wcześniej omówionego tym, że może skupiać także podmioty, niebędące przedsiębiorcami, które łączy dążenie do realizacji wspólnego celu.

Łączenie się producentów także w ramach tymczasowych inicjatyw o różnej naturze w celu promocji produktów jest sposobem wspólnego i zbiorowego podnoszenia wartości produktów jakościowych. Przykładem mogą być stowarzyszenia gmin, na terenie których wytwarzany jest produkt jakościowy, na przykład „Stowarzyszenia miast oleju ${ }^{25}$, ,Stowarzyszenie miast czereśni”, lub „drogi winne” (le strade del vino $\left.{ }^{26}\right)$. Często są one częścią złożonej strategii „,marketingu terytorialnego", mającej na celu propagowanie wiedzy o całych obszarach, w tym o występującej tam produkcji rolno-żywnościowej lub atutach turystyczno-rekreacyjnych. ${ }^{27} \mathrm{Sa}$ to inicjatywy, które mogą przybierać różną formę, jak targi, festiwale, degustacje, tematyczne krótkie kursy, konkursy, kampanie promocyjne. ${ }^{28}$ Uczestniczą w nich nie tylko rolnicy, ale też restauratorzy, hotelarze, handlowcy, podmioty publiczne,

25 Powstało w 1994 r. i zrzesza obecnie gminy z 17 regionów Włoch, mając na celu promocję lokalnej oliwy z oliwek oraz obszarów, w których jest wytwarzana.

26 Zob. przepisy krajowe ustanawiające drogi winne i oliwy, w tym obowiązkowe minimalne standardy jakości, Legge n. 268 del 27 luglio 1999 Disciplina delle strade del vino, Decreto Ministeriale 27 luglio 2000 Fissazione degli standard minimi di qualità per i percorsi individuati ai sensi della Legge 27 luglio 1999, n. 268 recante "Disciplina delle strade del vino". Na poziomie regionalnym zob. np. ustawę regionalną Regionu Toskanii: Legge Regionale 05 agosto 2003, n. 45 Disciplina delle strade del vino, dell'olio extravergine di qualità.

28 Zob. np. ustawę regionalną Regionu Abruzzo w sprawie festiwalu produktów regionalnych Abruzzo, L.R. 20 luglio 2016, n. 22 Disciplina in materia di sagra tipica dell'Abruzzo, delle feste popolari e dell'esercizio dell'attività temporanea di somministrazione di alimenti e bevande - Disposizioni in favore dei Centri di Ricerca del settore agricolo, (BURA nr 32 z 17.08.2016). 
jak muzea itp. ${ }^{29}$ Są to zatem strategie bardzo złożone, ale mogące przynieść więcej korzyści niż działanie indywidualne.

Małym przedsiębiorstwom rolno-żywnościowym, które dominują we Włoszech, trudno jest samodzielnie organizować i ponosić koszty promocji własnych produktów jakościowych, wprowadzać je na rynek, tak by uzyskały pewne miejsce jako produkt znany i o dobrej reputacji. Wspólne organizowanie strategii promocyjnych, zwłaszcza w odniesieniu do produktów związanych z obszarem geograficznym, którego prawa ochronne nie są monopolem jednego producenta, ale przysługują wszystkim wytwórcom z danego miejsca, nie tylko pozwala na podział kosztów, ale zwiększa szansę na skuteczne uwidocznienie produktu na rynku. ${ }^{30}$

\section{Formy wsparcia sprzedaży i promocji produktów regionalnych i tradycyjnych}

Innym sposobem promocji jakościowych produktów rolno-żywnościowych, niezwykle istotnym przede wszystkim dla małych gospodarstw rolnych, jest ich sprzedaż w krótkich łańcuchach sprzedaży. Może ona mieć różną formę od sprzedaży bezpośredniej w gospodarstwie, na rynkach lokalnych, poprzez e-commerce, dostawę do domu. Ich zaletą, którą dostrzegają konsumenci, jest możliwość zapewnienia świeżości produktu poprzez wyeliminowanie etapów pośrednich pomiędzy wytworzeniem produktu a jego zakupem, a co za tym idzie skróceniem czasu między jego produkcją a spożyciem. W długich łańcuchach sprzedaży konieczne są etapy przechowywania i konserwacji, które mogą wpłynąć na wartości organoleptyczne produktu. Ponadto konsekwencją tej formy komercjalizacji jest mniejsza znajomość pochodzenia produktu. Możliwość poznania bezpośrednio producenta oraz obszaru geograficznego pochodzenia produktu daje konsumentowi większą wiedzę o produkcie, który nabywa. Bezpośredni i osobisty kontakt między producentem a konsumentem umożliwia nawiązanie długotrwałych relacji opartych na zaufaniu, co może sprzyjać stabilności zbytu. ${ }^{31}$

We Włoszech sprzedaż bezpośrednia uregulowana jest bardzo szeroko, zarówno pod względem form jej realizacji, zakresu przedmiotowego oraz limitu dochodów, w ramach których pozostaje ona działalnością rolniczą. ${ }^{32}$ Dotyczy produktów pochodnych, otrzymanych w wyniku obróbki i przetworzenia produktów rolnych

A. Carbone, B. E. Velazquez, El sector Frutas y Hortalizas en Italia. Estructura, políticas y estrategias de valorización, [w]: S. Mili i S. Gatti (red.), Mercados agroalimentarios y globalización. Perspectivas para las producciones mediterráneas, Editorial CSIC, Colección Estudios Ambientales y Socioeconómico, 2005.

A. Carbone, La valorizzazione della qualità agroalimentare, op. cit. Ibidem.

Zob. art. 4 d. Igs. 228/2001 (Decreto Legislativo 18 maggio 2001, n. 228. Orientamento e modernizzazione del settore agricolo, a norma dell'articolo 7 della legge 5 marzo 2001, n. 228 „Orientamento e modernizzazione del settore agricolo, a norma dell'articolo 7 della legge 5 marzo. 2001, n. 57”, (GU nr 137 z 15.06.2001- Suppl.) Szerzej na ten temat [w:] A. Kapała, Sprzedaż produktów rolnych jako działalność rolnicza w prawie włoskim, „Przegląd Prawa Rolnego" 2011, nr 2, s. 179 i n. 
Wsparcie produktów regionalnych i tradycyjnych w ustawodawstwie krajowym...

lub zwierzęcych, w celu pełnego wykorzystania cyklu produkcyjnego przedsiębiorstwa. ${ }^{33}$ Jej przedmiotem nie muszą być wyłącznie produkty pochodzące $z$ własnego gospodarstwa, ale powinny być w przewadze. Tak sformułowany przepis umożliwia rolnikom łączenie swojej oferty sprzedaży. Również przedmiotem przetworzenia nie muszą być wyłącznie produkty otrzymane z własnej działalności rolniczej, wystarczy, że będą stanowić przewagę. Rolnik może zatem wykorzystywać w działalności przetwarzania produkty nabyte, a ponadto korzystać z usług podmiotów trzecich. Nie ma natomiast ograniczenia odnośnie do form prowadzenia sprzedaży oraz obszaru.

Coraz częściej w ostatnich latach we Włoszech grupy rolników wspólnie zarządzają relacjami z klientami w krótkim łańcuchu sprzedaży, zwiększając zakres oferty oraz oferując wspólne usługi dostawy do domu lub do miejsca pracy. Rozszerzanie oferty umożliwia lepsze dostosowanie podaży do popytu, zarówno pod względem ilości i rodzajów produktów, a jej koncentracja ułatwia klientowi zakupy, dzięki możliwości nabycia wielu artykułów w jednym miejscu.

Włoski ustawodawca wyodrębnił w sposób szczególny jeden z kanałów zbytu w krótkich łańcuchach sprzedaży, tj. tzw. rynki rolników (farmers’ markets), czyli targowiska przeznaczone do wykonywania sprzedaży bezpośredniej wyłącznie przez rolników. Wytyczne dla ich realizacji określa dekret Ministra Polityki Rolnej, Żywnościowej i Leśnej z dnia 20 listopada 2007 r. ${ }^{34}$ Wskazany akt prawny nie ma charakteru wiążącego. Zgodnie z art. 117 Konstytucji Republiki Włoch kompetencja ustawodawcza nie tylko w dziedzinie rolnictwa, ale również handlu jest zarezerwowana dla regionów. O utworzeniu rynków chłopskich decydują gminy w drodze uchwały regulaminu, o którym powiadamiają regiony. ${ }^{35} \mathrm{~W}$ powyższym dekrecie (art. 4) podkreśla się, że ich wprowadzenie ma na celu podnoszenie wartości produktów lokalnych, a zwłaszcza jakościowych, w tym z ChNP, ChOG lub produktów ekologicznych.

$\mathrm{Na}$ podstawie tej delegacji regiony ustanowiły bardzo wiele rynków rolnych. W 2008 r. w Sycylii zawarto porozumienia z gminami w celu powołania 42 rynków rolników. ${ }^{36}$

Region Lacjum wydał ustawę regionalną ustanawiającą dotacje (w formie refundacji $80 \%$ kosztów) na tworzenie rynków rolnych. ${ }^{37}$ Podobną dotację uchwalił

Decreto Mipaaf del 20 novembre 2007 Attuazione dell'articolo 1, comma 1065 della L. 27 dicembre 2006 n. 296 , sui mercati riservati all'esercizio della vendita diretta da parte degli imprenditori agricoli (GU nr 301 z 29.12.2007). Cyt. A. Kapała, Wymogi higieniczno-sanitarne w sprzedaży bezpośredniej produktów rolnych w prawie włoskim, „Przegląd Prawa Rolnego” 2013, nr 2, s. 131.

Finansowane przez regionalny dział rolnictwa Regionu Sycylii na podstawie ogłoszenia o konkursie opublikowanego w (GU Regione Sicilia z 11.04.2007 r.)

Legge regionale 24 dicembre 2008, n. 28 Interventi regionali per la promozione dei mercati riservati alla vendita diretta da parte imprenditori agricoli. (GU 3a Serie Speciale - Regioni nr 36 z 19.9.2009). 
region Toskanii w 2007 r. na realizację projektu „Krótki łańcuch - regionalna sieć waloryzacji produktów rolnych toskańskich ${ }^{38 "}$. Kolejnym przykładem jest ustawa regionalna Regionu Veneto ukierunkowania i wsparcia konsumpcji produktów rolnych pochodzenia regionalnego. W drodze nowelizacji zastąpiono określenie „produkty pochodzenia regionalnego" na „produkty rolne z zera kilometrów” (z wł. a chilometri zero), podkreślające aspekt bliskości rynku zbytu i krótkiego łańcucha dostaw. ${ }^{39}$ Ustawa przewiduje, że podmioty prowadzące usługi żywienia zbiorowego, zlecone przez instytucje publiczne, powinny zapewnić, że do przygotowania posiłków są stosowane produkty rolne pochodzenia regionalnego w nie mniej niż 50\% pod względem wartości produktów rolnych, także przetworzonych, w skali rocznej (art. 2 ustawy regionalnej regionu Veneto). Ponadto zobowiązuje gminy do zarezerwowania na co najmniej $20 \%$ powierzchni targowisk stanowisk dla rolników wykonujących sprzedaż bezpośrednią (art. 3 ust. 1 ustawy regionalnej regionu Veneto). W celu zachęcenia do zakupu regionalnych produktów rolnych oraz zapewnienia odpowiedniego informowania konsumentów o pochodzeniu i specyfice takich produktów, gminy wyznaczają tereny na realizację rynków rolników i rynku produktów lokalnych przeznaczonych tylko dla rolników (art. 3 ust. 2 ustawy regionalnej regionu Veneto).

Kolejnym przykładem jest ustawa regionalna Regionu Umbrii z dnia 10 lutego 2011 r. wsparcia tzw. „ludowych grup zakupowych” i promocji produktów rolno-żywnościowych jakościowych oraz tzw. ,z zera kilometrów” i z krótkich łańcuchów sprzedaży. ${ }^{40}$ Ustawa powiązuje wsparcie wskazanych form łączenia z wymogiem rozwoju sprzedaży bezpośredniej produktów rolnych lokalnych. Środki przeznaczone są na ,produkcję lokalną (dosłownie z zera kilometrów) i rozpowszechnianie produktów jakościowych, jako instrumentów służących ochronie konsumentów i środowiska", a także na ,promocję lokalnych produktów rolnych, produktów jakościowych i z krótkich łańcuchów, sprzyjając ich konsumpcji i sprzedaży, zapewniając odpowiednią informację konsumentom odnośnie do pochodzenia i specyfiki takich produktów i większą transparentność cen" (art. 1 ust. 2 i 3 ustawy regionalnej regionu Umbrii).

Przepisy nie określają formy prawnej dla takich podmiotów, które często tworzone są $\mathrm{w}$ formie grup nieuznanych (art. $36 \mathrm{i} \mathrm{n.} \mathrm{wł.} \mathrm{k.c.}{ }^{41}$ ) zgodnie $\mathrm{z}$ ustawą

39 Legge regionale 25 luglio 2008, n. 7 Norme per orientare e sostenere il consumo dei prodotti Agricoli di origine regionale (BUR nr 62/2008), zmieniona przez Legge regionale N. 3 del 22 gennaio 2010 Modifiche della legge regionale 25 luglio 2008, n. 7 „Norme per orientare e sostenere il consumo dei prodotti agricoli di origine regionale" (BUR nr 8 z 26.01.2010).

40 Legge regionale 10 febbraio 2011, n. 1, Norme per il sostegno dei gruppi di acquisto solidale e popolare (GASP) e per la promozione dei prodotti agroalimentari a chilomentri zero, da filiera Corta e di qualità.

41 Codice Civile Regio Decreto 16 marzo 1942, n. 262. Approvazione del testo del Codice civile. (042U0262) (GU nr 79 z 04.04.1942). 
nr 383/2000. ${ }^{42}$ Ten typ zrzeszenia, z punktu widzenia prawa, najczęściej związany jest z regulowaniem zakupów dóbr konsumpcyjnych (głównie) rolno-żywnościowych, dokonywanych w imieniu i na rzecz członków.

W kontekście socjologicznym te formy zgrupowania określane są jako ,green consumerism". Opierają się na założeniu, że konsumenci, pod warunkiem, że są poinformowani, a więc bardziej świadomi, mogą poprzez odpowiednie zakupy, wpłynąć na sposób, w jaki dobra będą produkowane. ${ }^{43}$ Ich działaniu przyświecają cele etyczno-środowiskowe i antymonopolistyczne. Dlatego łączenie się nie jest ograniczone jedynie do fazy zakupu dóbr. Służy wymianie informacji i jest instrumentem realizacji zakupów dóbr konsumpcyjnych, mających cechy pożądane przez daną grupę konsumentów, które wykraczają poza zwykłe potrzeby zaspokojenia potrzeb żywieniowych. Grupy mogą zawierać umowy z wybranymi dostawcami na podstawie kryteriów etycznych, środowiskowych, związanych ze sposobem prowadzenia produkcji, lub położenia w rejonie, w której działa grupa, w celu ograniczenia negatywnych skutków związanych z transportem. ${ }^{44}$ Te kwestie nie są jednak prawnie uregulowane, należąc do sfery swobody kontraktowej grupy. Aspekty prawne działania tej grupy dotyczą fazy sprzedaży produktów rolno-żywnościowych, zarządzanej przez grupę. W tym zakresie zgrupowanie skierowane na zakup dóbr konsumpcyjnych realizuje dwa główne efekty ekonomiczne: koncentrację popytu oraz skrócenie łańcucha dostaw. ${ }^{45}$

Włoski ustawodawca stworzył także kanał zbytu w ramach gospodarstwa agroturystycznego. Posiłki i napoje podawane w ramach agroturystyki powinny składać się nie tylko z własnych produktów, ale również produktów pochodzących od innych gospodarstw rolnych, położonych w danym regionie lub sąsiednich obszarach, które mogą być napojami alkoholowymi i spirytusowymi, z preferencją dla produktów typowych, oznaczonych jako ChNP, ChoG, Doc, Docg, ${ }^{46}$ lub będących na krajowej liście produktów tradycyjnych. ${ }^{47} \mathrm{~W}$ ten sposób agroturystyka jest kanałem zbytu, formą promocji i wsparcia lokalnych produktów tradycyjnych i dowartościowania obszarów, z których te produkty pochodzą. Także i w tym wypadku

Legge 7 dicembre 2000, n. 383 „Disciplina delle associazioni di promozione sociale” (GU nr 300 z 27.12.2000). nych zob. P. Allen, M. Kovach, The capitalist composition of organic: The potential of markets in fulfilling the promise of organic agriculture, "Agriculture and human values" 2000, nr 17, s. $221 \mathrm{i} \mathrm{n.}$ I. Canfora, Le nuove forme di commercializzazione dei prodotti alimentari: dalle vendite in rete ai "gruppi di acquisto solidale", [w]: M. Goldoni, E. Sirsi (red.), II ruolo del diritto nella valorizzazione e promozione dei prodotti agro-alimentari, Giuffrè Editore, Milano 2011, s. 245-246.

45 Zob. szerzej w I. Canfora, s. 246.

46 Doc (Denominazione d'origine controllata) oraz Docg (Denominazione d'origine controllata e garantita) to krajowy znak towarowy włoskich win.

47 Zob. art. 2 ust. 3 pkt b włoskiej ustawy o agroturystyce: Legge 20 febbraio 2006 n. 96 „Disciplina dell’agriturismo"(GU nr 63 z 16.03.2006). Szerzej na ten temat zob. A. Kapała, Agroturystyka jako rodzaj działalności rolniczej w prawie włoskim, „Przegląd Prawa Rolnego” 2007, nr 2, s. 203 i n. Art. 4 ust. 4 zobowiązuje regiony do uregulowania działalności podawania posiłków i napojów w ramach agroturystyki z uwzględnieniem produktów lokalnych i typowych, „w celu przyczynienia się do promocji regionalnych produktów rolno-żywnościowych”. 
ustawodawca zachęca (a nawet zobowiązuje) do współpracy producentów rolnych i żywnościowych, która, podobnie jak wszystkie formy łączenia się, jest ważnym elementem wzmacniania ich oferty, a tym samym ich konkurencyjności.

\section{Zakończenie}

Włoskie rozwiązania mające na celu promocję produktów jakościowych, skoncentrowane są na poprawie ich komercjalizacji na rynkach lokalnych. Są to instrumenty o charakterze publicznoprawnym, jak np. przepisy dotyczące tworzenia gminnych targowisk rolnych, zobowiązujące do przeznaczania określonej powierzchni targowisk na produkty lokalne, do podawania w żywieniu zbiorowym produktów regionalnych. Do prywatnoprawnych instrumentów można zaliczyć przepisy umożliwiające rolnikom łączenie ich produktów rolnych w procesie przetwarzania i sprzedaży bezpośredniej oraz współdziałania w różnych formach organizacyjnych podmiotów zrzeszeniowych i swobodnego kształtowania stosunków umownych.

Sukces sprzedaży produktów jakościowych zależy od ich komercyjnego dowartościowania, na rzecz którego producenci muszą współpracować. Włoskie prawo zachęca do współpracy nie tylko producentów, ale różne podmioty prywatne i publiczne związane z obszarem, z którego produkt pochodzi, wprowadzając innowacyjne i proste formy prawne łączenia się, pozbawione biurokracji, a ukierunkowane na zwiększenie konkurencyjności i osiągnięcie wspólnego celu, jak np. wskazane w analizowanym PROW tymczasowe stowarzyszenia przedsiębiorstw i stowarzyszenia wspólnego celu. Takie formy pozwalają na realizację skomplikowanych strategii tzw. „marketingu terytorialnego” lokalnych produktów jakościowych.

Włoski prawodawca krajowy i regionalny wprowadza instrumenty prawne łączenia się nie tylko po stronie podaży, w odniesieniu do producentów rolno-żywnościowych, ale również po stronie popytu, wspierając tzw. ludowe grupy zakupowe, sprzyjając tym samym koncentracji popytu i lepszemu dostosowaniu oferty podaży do popytu. Jest to instrument, mogący być odpowiedzią na istotny problem sektora rolno-spożywczego, zwłaszcza małych producentów rolnych, działających w krótkich łańcuchach sprzedaży, tj. rozdrobnienia po stronie popytu i podaży oraz ich wzajemnego niedostosowania. Na szczególną uwagę zasługują również przepisy dotyczące podawania w posiłkach w ramach agroturystyki nie tylko produktów pochodzących z własnego gospodarstwa, ale także produktów regionalnych. Wydaje się, że mogą one posłużyć jako przykład dla polskiego ustawodawcy. 
Wsparcie produktów regionalnych i tradycyjnych w ustawodawstwie krajowym...

SUPPORT FOR REGIONAL AND TRADITIONAL PRODUCTS IN THE NATIONAL LEGISLATION ON THE EXAMPLE OF ITALIAN LAW

Keywords: regional agricultural products and foodstuffs, quality scheme, short food chain, Italian legislation

The aim of the paper is to present how the Italian legislature supports the promotion and sale of broadly understood regional and traditional products, including the products covered by EU quality system. It analyses rules for the implementation in some regional Rural Development Programs measure under art. 16 of EU Regulation 1305/2013 and the national and regional regulations concerning various forms of promotion and sale of products.

Italian solutions to promote quality products, are focused on improving their commercialization in local markets in the short supply chain. These are the rules for the creation of farmers' markets; destination of specific area in the municipal agricultural markets for local products; administration of regional products in agritourism; provisions enabling farmers to combine their agricultural and food products in the processing and direct sales, as well as providing a very broad catalog forms of union, both on the supply side (with respect to the participants in the production chain) as well as on the demand side, by creating the so-called folk purchasing groups.

\section{Bibliografia:}

Allen P., Kovach M., The capitalist composition of organic: The potential of markets in fulfilling the promise of organic agriculture, ,Agriculture and human values” 2000, $\mathrm{nr} 17$.

Carbone A., La valorizzazione della qualitŕ agroalimentare: diverse strategie a confronto, Agriregionieuropa 2016, nr 2, www.agriregionieuropa.univpm.it.

Canfora I., Le nuove forme di commercializzazione dei prodotti alimentari: dalle vendite in rete ai "gruppi di acquisto solidale", [w:] M. Goldoni, E. Sirsi (red.), Il ruolo del diritto nella valorizzazione e promozione dei prodotti agro-alimentari, Milano 2011.

Carbone A., Velazquez B. E., El sector Frutas y Hortalizas en Italia. Estructura, políticas y estrategias de valorización, [w]: S. Mili i S. Gatti (red.), Mercados agroalimentarios y globalización. Perspectivas para las producciones mediterráneas, Editorial CSIC, Colección Estudios Ambientales y Socioeconómico, 2005.

Elkington J., Hailes J., The Green consumer guide, London 1998.

Kapała A., Sprzedaż produktów rolnych jako działalność rolnicza w prawie włoskim, „Przegląd Prawa Rolnego" 2011, nr 2.

Kapała A., Wymogi higieniczno-sanitarne w sprzedaży bezpośredniej produktów rolnych w prawie włoskim, „Przegląd Prawa Rolnego” 2013, nr 2. 


\section{Anna Kapała}

Kapała A., Agroturystyka jako rodzaj działalności rolniczej w prawie włoskim, „Przegląd Prawa Rolnego" 2007, nr 2. 